\title{
Developing a One-Step Multiplex PCR Assay for Rapid Detection of Four Stubby-Root Nematode Species, Paratrichodorus allius, P. minor, P. porosus, and Trichodorus obtusus
}

Danqiong Huang, Guiping Yan, ${ }^{\dagger}$ and Neil Gudmestad, North Dakota State University, Department of Plant Pathology, Fargo, ND 58102; Weimin Ye, North Carolina Department of Agriculture and Consumer Services, Raleigh, NC 27607; Jonathan Whitworth, USDA-ARS, Aberdeen, ID 83210; Kenneth Frost, Oregon State University, Hermiston Agricultural Research and Extension Center, Hermiston, OR 97838; William Crow, University of Florida, Entomology and Nematology Department, Gainesville, FL 32611; and Abolfazl Hajihassani, University of Georgia, Department of Plant Pathology, Tifton, GA 31794

\begin{abstract}
Four trichodorid species, Paratrichodorus allius, P. minor, P. porosus, and Trichodorus obtusus, were found in multiple states in the United States. Traditional diagnosis based on morphology and morphometrics is laborious and requires an experienced taxonomist. Additionally, end-point diagnosis using PCR was only available for $P$. allius. To increase diagnostic efficiency and reduce costs, a one-step multiplex PCR assay was developed to simultaneously identify these four species using one PCR reaction. Available sequences of $18 \mathrm{~S}$ ribosomal DNA and internal transcribed spacer 1 (ITS1) region of these species were aligned and five primers were designed. The conserved forward primer located in the $18 \mathrm{~S}$ region, in combination with the species-specific antisense primer in the ITS1 region, amplified a single distinctive PCR fragment for each species (421/425 bp for

P. allius, $190 \mathrm{bp}$ for $P$. minor, $513 \mathrm{bp}$ for $P$. porosus, and $353 \mathrm{bp}$ for $T$. obtusus). In silico analysis with 10 other trichodorid species and experimental analysis using samples with these four species, 20 other plant-parasitic and three non-plant-parasitic nematodes demonstrated high specificity with the primers designed. The multiplex PCR amplified desirable fragments using a set of artificially mixed templates containing one, two, three, or four targeted species. The reliability of multiplex PCR results was demonstrated by using nematode populations isolated from infested fields from diverse geographic regions in eight states. The multiplex PCR-based tool developed in this study for the first time provides a simple, rapid, and costfriendly assay for accurate diagnosis of the four major trichodorid nematodes in the United States.
\end{abstract}

The stubby-root nematodes Paratrichodorus Siddiqi, 1974 and Trichodorus Cobb, 1913 in the family Trichodoridae (Thorne, 1935) Siddiqi, 1961 are plant ectoparasitic nematodes with signature cigar-shaped bodies and curved onchiostyles. They are important because they cause direct feeding damage and can vector certain viruses including Tobacco rattle virus, Pea-early browning virus, and Pepper ringspot virus, which cause severe economic damage on crops, especially in potato and ornamental bulbous crops (Decraemer 1995; Harrison and Robinson 1986). In the United States, Paratrichodorus teres (Hooper, 1962) (syn. Trichodorus teres, T. flevebsus), $P$. allius (Jensen, 1963), P. minor (Colbran, 1956) (syn. Nanidorus minor, N. christiei, P. christiei, P. obesus, T. christiei, T. minor, T. obesus), P. porosus (Allen, 1957) (syn. Atlantadorus porosus, T. bucrius, T. porosus), P. renifer (syn. N. renifer), and T. obtusus (Cobb, 1913) (syn. T. proximus) are present (Decraemer 1995; Kumari and Subbotin 2012; Riga et al. 2007; Hajihassani et al. 2018). Four of these species are commonly found in multiple states, including $P$. allius which is distributed in seven states (Lopez-Nicora et al. 2014; Mojtahedi et al. 2000; Yan et al. 2016a, b), P. minor in 31 states (CABI/EPPO 2002), P. porosus in 10 states (CABI/EPPO 2009), and T. obtusus in seven states (Crow 2005). A broad range of hosts for these four species, including potato, common grain, turfgrasses, and vegetables, occur in the United States (Crow 2004,

${ }^{\dagger}$ Corresponding author: Guiping Yan; E-mail: guiping.yan@ndsu.edu

Funding: This research was supported by United States Department of Agriculture (USDA)-National Institute of Food and Agriculture (NIFA)-Special Crop Research Initiative award number 2014-51181-22373 and USDANIFA Hatch Multistate project number ND02233.

*The $\boldsymbol{e}$-Xtra logo stands for "electronic extra" and indicates that one supplementary figure and one supplementary table are published online.

Accepted for publication 24 August 2018.

() 2019 The American Phytopathological Society
2005; Lopez-Nicora et al. 2014; Mojtahedi and Santo 1999; Shaver et al. 2016; Sheedy et al. 2010; Ye et al. 2015; Zeng et al. 2012; Hajihassani et al. 2018). Additionally, the three Paratrichodorus spp. are considered to be vectors of tobraviruses (Decraemer and Robbins 2007; Huang et al. 2018).

It has been reported that approximately $10 \%$ of field populations of $P$. allius were viruliferous in the Pacific Northwest of the United States, resulting in significant economic losses to the potato industry (Mojtahedi et al. 2000). The species P. minor and T. obtusus are known to damage the root system of many turfgrasses, such as St. Augustinegrass (Rhoades 1965), bermudagrass (Crow and Welch 2004), and zoysiagrass (Shaver et al. 2013). The species P. porosus damaged maize and sorghum crops and affected forage production in North Carolina, U.S. (Chévres-Román et al. 1971) and induced black-blot disease negatively impacting the Chinese yam industry (Nishizawa 1973). Given the large number of economic hosts negatively affected by stubby-root nematodes, an efficient, time- and cost-saving diagnostic tool would be highly beneficial for determination of rotational planting plans and chemical control application to mitigate crop damage and reduce nematode spread. For example, it would not be recommended to establish turfgrass, corn, or sorghum in a field infested with $P$. minor. Instead, summer legumes could be planted to maintain low population densities of this stubby-root nematode species in the soil (Crow 2004). In a potato field infested with $P$. allius, a treatment of metam sodium and 1,3-dichloropropene might be considered to control the nematode and its associated Tobacco rattle virus causal agent of corky ringspot disease (Ingham et al. 2000, 2007).

Differentiation of stubby-root nematodes from other plantparasitic nematodes is easily accomplished based on morphological characters, while differentiation of stubby-root nematode species from each other is difficult as the differences in morphometrics are minor among closely related species (Decraemer and Baujard 1998). Two stubby-root nematode species, P. allius and P. teres, are morphologically similar and could only be separated by the vaginal shape of females and the number of ventromedian precloacal supplements of males (Riga and Nelison 2005). However, the vaginal shape is easily affected by fixation and handling during the 
specimen preparation, and males of some Paratrichodorus species are rarely found. Hence, the accuracy of morphological identification of nematode species is challenging. The partial 18S rDNA and ITS1 region of $P$. allius and $P$. teres were sequenced, and their alignment suggested that the sequence identity of these two species (GenBank accessions: AM087124.1 and AM087125.1) was only 94\% (Riga et al. 2007). Subsequently, a molecular diagnosis method was introduced to identify these two morphological closely related species, using end-point duplex PCR with species-specific primers located in the ITS1 region (Riga et al. 2007).

To date, several molecular methods have been developed to identify, differentiate, and quantify stubby-root nematode species, such as PCR followed by a restriction fragment length polymorphism analysis (PCR-RFLP) (Duarte et al. 2011; Kumari and Subbotin 2012), end-point single or duplex PCR with species-specific primers (Boutsika et al. 2004; Huang et al. 2017b; Riga et al. 2007), and quantitative real-time PCR monitoring amplicon production during each cycle (Holeva et al. 2006; Huang et al. 2017a; 2018). Among these PCR-RFLP technique requires additional steps that are timeconsuming, while quantitative real-time PCR focuses on the quantification of population density, which is more expensive. In addition, quantitative real-time PCR requires additional professional training on techniques and data normalization and presentation, which limits its application for species identification. The end-point single PCR with species-specific primers is more suitable as an inexpensive and routine diagnostic service, with the advantage of lower cost and time, and requires less technical skill. Currently, diagnoses using end-point single PCR with species-specific primers are available for $P$. allius, $P$. teres, $P$. macrostylus, $P$. pachydermus, $T$. primitivus, and T. similis (Boutsika et al. 2004; Huang et al. 2017b; Riga et al. 2007), but not for the other three widely distributed and economically important stubby-root nematodes, P. minor, P. porosus, and T. obtusus.

The end-point single PCR with only one pair of primers is simpler than multiplex PCR with multiple primer pairs in its design, implementation, and optimization. However, the development and utilization of three individual end-point single PCR assays for specific identification of these three species are laborious and come at higher costs. Additionally, multiple tests with several different end-point single PCR for nematode species identification is not recommended when limited DNA template is available. Thus, the multiplex PCR assay has the advantage of simultaneous identification of multiple gene targets using a single reaction, minimizing the amount of DNA template and PCR reagents necessary to complete a diagnosis. Despite the complexity of multiplex PCR assay development, multiplex PCR methods have been successfully developed in differentiation of various pathogens, such as bacteria (Cui et al. 2016), fungi (Cho et al. 2016), and nematodes (Filipiak et al. 2017). For nematode species differentiation, multiplex PCR protocols were developed for Xiphinema spp. (Wang et al. 2003), Meloidogyne spp. (Hu et al. 2011), and Bursaphelenchus spp. (Filipiak et al. 2017), with a maximum of four species identified by a single PCR reaction (Wang et al. 2003). For stubby-root nematode species identification, a duplex PCR was developed to detect $P$. allius and $P$. teres simultaneously (Riga et al. 2007). To our knowledge, there is no multiplex PCR available for other stubby-root nematode species.

Farmers may want to know what species of plant-parasitic nematodes is present in their fields in order to make better nematode management decisions through crop rotation or use of resistant crops. Information on nematode infestations would commonly come from professional soil diagnostic services. The multiplex PCR method is more preferable than several end-point single PCR assays to improve the efficiency and reduce the cost of nematode diagnosis. However, there is no report of a PCR technique for simultaneous detection and identification of $P$. allius, $P$. minor, $P$. porosus, and $T$. obtusus which are widely present and economically important trichodorid species in the United States. The main objective of this study was to develop a convenient one-step (in a single PCR reaction) multiplex PCR-based assay with the capability of simultaneous and unambiguous identification of $P$. allius, $P$. minor, $P$. porosus, and $T$. obtusus, using single target nematodes. The molecular characterization of $18 \mathrm{~S}$ rDNA, $28 \mathrm{~S}$
rDNA, 5.8S rDNA, ITS1 rDNA, and ITS2 rDNA sequences were reported previously for these four nematode species (Huang et al. 2018), which accelerated the development of multiplex PCR-based diagnostic method in this study.

\section{Materials and Methods}

Nematode materials and DNA extraction from single nematodes. In 2016-2018, stubby-root nematode infested soil samples were collected by our group from North Dakota and Minnesota, and also provided by collaborators from Florida, Idaho, Oregon, and Nebraska (Table 1). Additional nematode suspensions containing stubby-root nematodes were obtained from North Carolina and Georgia (Table 1). These nematode samples were collected from grass, alfalfa, barley, corn, soybean, onion, potato, and sugar beet fields. For the soil samples, vermiform nematodes were extracted from $200 \mathrm{~g}$ of soil by sieving and decanting followed by sugar centrifugal flotation methods (Jenkins 1964). Stubby-root nematodes were hand-picked from nematode suspensions under a dissecting microscope (Zeiss stemi 305 Lab microscope, Zeiss). The genomic DNA from single individuals of each stubby-root nematode species was extracted using Proteinase K method (Huang et al. 2018; Kumari and Subbotin 2012). For each soil sample or nematode suspension, at least three genomic DNA preparations of stubby-root nematode individuals were used as replicates. The DNA extracts were stored in $-20^{\circ} \mathrm{C}$ for subsequent experiments.

Multiple sequence alignment, primer design, and in silico analysis. Multiplex PCR primers for differentiation of $P$. allius, $P$. minor, $P$. porosus, and $T$. obtusus were targeted on the ITS1 rDNA, which is the most variable region when compared with the $18 \mathrm{~S}$ rDNA and $28 \mathrm{~S}$ rDNA regions. The ITS1 rDNA sequences used for multiple sequence alignment and comparison were retrieved from GenBank, including eight sequences of $P$. allius (MG938575-MG938582), two sequences of P. porosus (MG938570, MG938571), one sequence of $P$. minor (MG938572), and two sequences of T. obtusus (MG938573, MG938574). The alignment was performed using ClustalX (Thompson et al. 1997), and primer selections were carried out using the PrimerSelect module in DNASTAR software package (Lasergene, Madison, WI, USA). To minimize the number of primers present in a PCR reaction, the forward primer was nonspecific while reverse primers were species-specific (Table 2; Supplementary Fig. S1). Therefore, the universal forward primer was located in the conserved region of $18 \mathrm{~S}$ rDNA and the compatible reverse primers were selected under default settings with additional criteria including: (i) located in ITS1 rDNA region unique for each species, (ii) no formation of severe primer hairpins, self-dimers, and pair-dimers, (iii) melt temperature (Tm) differences among primers less than $5^{\circ} \mathrm{C}$, and (iv) amplified fragments differ from each other by at least $50 \mathrm{bp}$ in order to clearly distinguish the four species on an agarose gel.

Primer specificity was assessed by in silico analysis (Okubara et al. 2008; Schroeder et al. 2006; Yan et al. 2008), using nematode species in the genera of Paratrichodorus and Trichodorus that were available in the GenBank database (Supplementary Table S1). There were 81 isolates from 14 trichodorid nematode species in the analysis, including 26 isolates from $P$. allius, 19 isolates from $P$. porosus, 10 isolates from $P$. minor, six isolates from $P$. renifer, three isolates from each of T. pakistanensis and T. similis, two isolates from each of $P$. macrostylus, $P$. pachydermus, T. nanjingensis, T. obtusus, T. primitivus, and $T$. sparsus, and one isolate of each of $P$. teres and T. cedarus. No PCR amplification was considered when the primer-template duplex stability $(\Delta \mathrm{G})$ was presented as insignificant or poor primer-template duplex stability $(\Delta \mathrm{G}>-31 \mathrm{kcal} / \mathrm{mol})$. Primers were synthesized by Eurofin MWG Operon LLC (Huntsville, AL).

Multiplex polymerase chain reaction. The multiplex PCR protocol for differentiating the targeted nematode species, optimal PCR reaction, and thermocycler conditions were developed using previously published procedures (Henegariu et al. 1997). To initiate this work, a singleplex PCR for all four target species, with one primer pair consisting of the universal forward primer and one of the species-specific reverse primers, was set up using the same 
protocol, including the same concentration of each PCR reagent and cycling conditions. The initial singleplex PCR was carried out at conditions including $1 \times \mathrm{PCR}$ buffer, $1.5 \mathrm{mM} \mathrm{MgCl}_{2}, 0.2 \mathrm{mM} \mathrm{dNTP}$, and $0.5 \mu \mathrm{M}$ of each primer, with annealing temperature calculated by the PrimerSelect software. Accordingly, the multiplex PCR was conducted by adding all the primers into the PCR reaction as the protocol of the single, basic PCR. PCR products were separated in $2.5 \%$ agarose gel at 100 volts for $40 \mathrm{~min}$ and documented using the AlphaImager Gel Documentation System (Proteinsimple Inc., Santa Clara, CA, USA). Based on the banding patterns of PCR products, the multiplex PCR protocol was further optimized by adjusting the annealing temperature, extension time, and each primer concentration, as recommended by Henegariu et al. (1997). The final optimized multiplex PCR used in this study for stubby-root nematode species identification was executed in a $25-\mu \mathrm{l}$ volume including $1.0 \mu \mathrm{l}$ of template, $1.5 \mathrm{mM} \mathrm{MgCl} 2,0.2 \mathrm{mM}$ dNTP, $0.5 \mu \mathrm{M}$ of UnivF3 (universal forward primer), $0.12 \mu \mathrm{M}$ of PaR1 ( $P$. allius specific reverse primer), $0.2 \mu \mathrm{M}$ of PmR1 (P. minor specific reverse primer), $0.2 \mu \mathrm{M}$ of PpR1 (P. porosus specific reverse primer), $0.16 \mu \mathrm{M}$ of ToR2 (T. obtusus specific reverse primer), $1 \times$ Colorless GoTaq Flexi PCR buffer, and 1.0 U GoTaq Flexi DNA Polymerase (Promega, Madison, WI, USA). The PCR cycling conditions were: one cycle of $94^{\circ} \mathrm{C}$ for $3 \mathrm{~min}$, followed by 35 cycles of $94^{\circ} \mathrm{C}$ for $30 \mathrm{~s}, 60^{\circ} \mathrm{C}$ for $30 \mathrm{~s}$, and $72^{\circ} \mathrm{C}$ for $1 \mathrm{~min} 20 \mathrm{~s}$, and a final cycle of $72^{\circ} \mathrm{C}$ for $10 \mathrm{~min}$.
Multiplex PCR validation and diagnosis of Paratrichodorus allius, $\boldsymbol{P}$. minor, $P$. porosus, and Trichodorus obtusus. To determine the specificity of the multiplex PCR for the nematode species targeted, PCR was performed with a set of DNA samples from target and nontarget nematode individuals (Table 3 ) that were used in previous studies (Huang et al. 2017a, b; 2018). A total of 13 target nematode samples and 23 nontarget nematode samples were used, including all four target stubby-root nematode species, five cyst nematode species (Heterodera glycines, $H$. schachtii, Cactodera milleri, Globodera ellingtonae, and G. pallida), one root-knot nematode species (Meloidogyne chitwoodi), six root-lesion nematode species (Pratylenchus penetrans, $P$. neglectus, $P$. scribneri, $P$. thornei, $P$. zeae, and Pratylenchus sp.), one lance nematode species (Hoplolaimus stephanus), one unknown stunt nematode (Tylenchorhynchus sp.), one spiral nematode (Helicotylenchus microlobus), one unidentified dagger nematode species (Xiphinema sp.), one ring nematode (Mesocriconema sp.), one pin nematode (Paratylenchus nanus), and three non-plant-parasitic nematodes (Table 3).

To further validate the specificity and capability of the protocol on species differentiation, multiplex PCR was evaluated with a set of artificially prepared DNA mixtures consisting of two, three, and four target nematode species at the ratio of $1: 1,1: 1: 1$, and $1: 1: 1: 1$, respectively. Additionally, the species of stubby-root nematodes from field soils of diverse geographic regions (Table 1) were determined by the

Table 1. Stubby-root nematode samples used in this study

\begin{tabular}{|c|c|c|c|c|c|c|}
\hline Sample ID & County, state & Sampling date & Crop & Multiplex PCR fragment (bp) & Species identity & Species confirmed by ${ }^{a}$ \\
\hline 7103 & Sargent, ND & 09/2017 & Potato & $421 / 425$ & Paratrichodorus allius & Species-specific PCR \\
\hline 7105 & Sargent, ND & $09 / 2017$ & Potato & $421 / 425$ & P. allius & Species-specific PCR \\
\hline 7106 & Sargent, ND & $09 / 2017$ & Potato & $421 / 425$ & P. allius & Species-specific PCR \\
\hline SB1 & Clay, MN & $06 / 2017$ & Sugarbeet & $421 / 425$ & P. allius & Species-specific PCR \\
\hline SB51 & Clay, MN & $07 / 2017$ & Sugarbeet & $421 / 425$ & P. allius & Species-specific PCR \\
\hline IDL1 & Fremont, ID & $10 / 2017$ & Potato & $421 / 425$ & P. allius & Species-specific PCR \\
\hline IDS7 & Fremont, ID & $10 / 2017$ & Alfalfa & $421 / 425$ & P. allius & Species-specific PCR \\
\hline IDB1 & Fremont, ID & $10 / 2017$ & Barley & $421 / 425$ & P. allius & Species-specific PCR \\
\hline SH1 & Umatilla, OR & $12 / 2016$ & Potato & $421 / 425$ & P. allius & Species-specific PCR \\
\hline $\mathrm{SH} 3$ & Umatilla, OR & $12 / 2016$ & Potato & $421 / 425$ & P. allius & Species-specific PCR \\
\hline 7524 & Umatilla, OR & $12 / 2016$ & Potato & $421 / 425$ & P. allius & Species-specific PCR \\
\hline MS2 & $\mathrm{NE}$ & $03 / 2017$ & Potato & $421 / 425$ & P. allius & Species-specific PCR \\
\hline MS5 & $\mathrm{NE}$ & $03 / 2017$ & Potato & $421 / 425$ & P. allius & Species-specific PCR \\
\hline GJ-10 & $\mathrm{NE}$ & $03 / 2017$ & Potato & $421 / 425$ & P. allius & Species-specific PCR \\
\hline $\mathrm{CSS} 4$ & NE & $05 / 2017$ & Potato & $421 / 425$ & P. allius & Species-specific PCR \\
\hline CSS10 & $\mathrm{NE}$ & $05 / 2017$ & Potato & $421 / 425$ & P. allius & Species-specific PCR \\
\hline NEB8 & NE & $10 / 2017$ & Potato & $421 / 425$ & P. allius & Species-specific PCR \\
\hline NEB13 & $\mathrm{NE}$ & $10 / 2017$ & Potato & $421 / 425$ & P. allius & Species-specific PCR \\
\hline 34536 & Cumberland, $\mathrm{NC}$ & $05 / 2016$ & Corn & 190 & P. minor & DNA sequencing \\
\hline 34537 & Lee, NC & $05 / 2016$ & Corn & 190 & P. minor & DNA sequencing \\
\hline 34538 & Lee, $\mathrm{NC}$ & $05 / 2016$ & Corn & 190 & P. minor & DNA sequencing \\
\hline 32943 & Nash, NC & $05 / 2016$ & Soybean & 190 & P. minor & DNA sequencing \\
\hline UGA & Tattnall, GA & $02 / 2018$ & Onion & 190 & P. minor & DNA sequencing \\
\hline FL48 & Marion, FL & $05 / 2016$ & Grass & 353 & Trichodorus obtusus & DNA sequencing \\
\hline FL50 & Marion, FL & $05 / 2016$ & Grass & 353 & T. obtusus & DNA sequencing \\
\hline
\end{tabular}

a The species of $P$. allius was confirmed by species-specific PCR developed by Huang et al. (2017b); the species of $P$. minor and T. obtusus were confirmed by direct sequencing of PCR products amplified by BL18/5818, as described by Huang et al. (2018). The DNA sequencing was performed by Genscript Corporation (Piscataway, NJ, USA).

Table 2. Universal and species-specific primers used in this study

\begin{tabular}{lllll}
\hline Primer name & Sense & \multicolumn{1}{c}{ Sequence $\left(\mathbf{5}^{\prime} \mathbf{- 3}\right.$ ') } & Primer location & \multicolumn{1}{c}{ Used for } \\
\hline D3A & Forward & GACCCGTCTTGAAACACGGA & 28S rDNA & Testing the presence of template DNA \\
D3B & Reverse & TCGGAAGGAACCAGCTACTA & 28S rDNA & \\
BL18 & Forward & CCCGTCGMTACTACCGATT & 18S rDNA & Sequencing for species identity confirmation \\
5818 & Reverse & ACGARCCGAGTGATCCAC & 5.8S rDNA & \\
UnivF3 & Forward & GTAACAAGGTTCCGTAGGTGAA & 18 rDNA & Multiplex PCR universal primer \\
PaR1 & Reverse & AGTCGACGTAGGTACCCAACAAAC & ITS1 rDNA & Specific for Paratrichodorus allius \\
PmR1 & Reverse & GGCGATGCTTGCGGGTGTG & ITS1 rDNA & Specific for P. minor \\
PpR1 & Reverse & GTACAGTTTTATCGTGCCGTTAG & ITS1 rDNA & Specific for P. porosus \\
ToR2 & Reverse & ACAAGCAAGCAAGCGGTCTC & ITS1 rDNA & Specific for Trichodorus obtusus \\
\hline
\end{tabular}


multiplex PCR using three independent DNA extracts from single nematodes in each sample. The accuracy of multiplex PCR diagnosis was evaluated by sequencing ITS1 rDNA region amplified by primers BL18/5818 (Huang et al. 2018). As an alternative, for P. allius, the species identity was confirmed by the species-specific singleplex PCR (Huang et al. 2017b). Before being subjected to the multiplex PCR, the quality of all DNA used in the study was checked by amplification with a set of universal primers D3A/D3B (Al-Banna et al. 1997).

\section{Results}

Selection and specificity of multiplex PCR primers. According to the sequence alignment performed by ClustalX using available information from GenBank, the $18 \mathrm{~S}$ rDNA region was more conserved than the ITS1 region. Hence, the universal forward primer UnivF3 was chosen from the 18S rDNA region in positions 747-769 for $P$. allius (MG938579 and MG938580), P. porosus (MG938571), and T. obtusus (MG938573), and positions 745-767 for $P$. minor (MG938572). The compatible species-specific reverse primers were selected from the ITS1 region in the positions 1236-1259 for $P$. porosus (MG938571), 916-934 for P. minor (MG938572), and 1080-1099 for T. obtusus (MG938573), resulting in expected PCR fragment sizes of 513, 190, and 353 bp for P. porosus, P. minor, and T. obtusus, respectively. Due to the sequence polymorphism, the specific reverse primer for $P$. allius was located in the positions 1150-1173 (MG938579) or 1146-1169 (MG938580) for different isolates, resulting in expected PCR fragment sizes of $425 \mathrm{bp}$ (MG938579) or $421 \mathrm{bp}$ (MG938580).

As expected, in silico analysis suggested that the primer UnivF3 formed a stable hybrid $(\Delta \mathrm{G}>-31 \mathrm{kcal} / \mathrm{mol})$ with all 14 stubbyroot nematode species examined, including seven from Paratrichodorus spp. and seven from Trichodorus spp. Meanwhile, the species-specific reverse primers only formed a stable hybrid with all isolates of the target nematode species, revealing the specificity of each primer set for its target species amplification. Moreover, the primer specificity was further tested by experimental PCR using DNA of four target stubby-root nematode species collected from multiple states, 18 nontarget plant-parasitic nematode species, and three free-living nematode species (Table 3 ). All eight DNA samples of $P$. allius from five states produced one fragment with the expected size using the multiplex PCR. Single fragments with the expected sizes were produced when DNA extracts from one isolate of $P$. $m i$ nor, two isolates of $P$. porosus, and two isolates of T. obtusus from different states were used as templates in PCR (Table 3). No PCR products were observed using DNA extracts from samples of 23 nontarget nematodes as template and the nontemplate control which used sterilized $\mathrm{ddH}_{2} \mathrm{O}$ in place of a DNA template in the PCR reaction. Amplification of all DNA extracts of nematodes occurred when the

Table 3. Nematode species used in this study to test the specificity of multiplex PCR assay

\begin{tabular}{|c|c|c|c|c|c|c|c|}
\hline \multirow[b]{2}{*}{ Code $^{\mathbf{a}}$} & \multirow[b]{2}{*}{ Species } & \multirow[b]{2}{*}{ State } & \multirow[b]{2}{*}{ Crop } & \multicolumn{4}{|c|}{ Multiplex PCR banding pattern ${ }^{b}$} \\
\hline & & & & Pa (421/425 bp) & Pm (190 bp) & Pp (513 bp) & To (352 bp) \\
\hline 1 & Paratrichodorus allius & ND & Potato & + & - & - & - \\
\hline 2 & P. allius & ND & Field pea & + & - & - & - \\
\hline 3 & P. allius & $\mathrm{MN}$ & Sugarbeet & + & - & - & - \\
\hline 4 & P. allius & MN & Sugarbeet & + & - & - & - \\
\hline 5 & P. allius & ID & Potato & + & - & - & - \\
\hline 6 & P. allius & ID & Potato & + & - & - & - \\
\hline 7 & P. allius & WA & Potato & + & - & - & - \\
\hline 8 & P. allius & OR & Potato & + & - & - & - \\
\hline 9 & P. minor & $\mathrm{NC}$ & Soybean & - & + & - & - \\
\hline 10 & P. porosus & SC & Spinach & - & - & + & - \\
\hline 11 & P. porosus & $\mathrm{NC}$ & Soybean & - & - & + & - \\
\hline 12 & Trichodorus obtusus & $\mathrm{SC}$ & Grass & - & - & - & + \\
\hline 13 & T. obtusus & FL & Grass & - & - & - & + \\
\hline 14 & Cactodera milleri & MN & Potato & - & - & - & - \\
\hline 15 & Globodera ellingtonae & OR & Potato & - & - & - & - \\
\hline 16 & G. pallida & ID & $/ \mathrm{c}$ & - & - & - & - \\
\hline 17 & Heterodera glycines & ND & Potato & - & - & - & - \\
\hline 18 & H. schachtii & OR & Sugarbeet & - & - & - & - \\
\hline 19 & Meloidogyne chitwoodi & WA & Potato & - & - & - & - \\
\hline 20 & Pratylenchus penetrans & MD & 1 & - & - & - & - \\
\hline 21 & P. neglectus & ND & Wheat & - & - & - & - \\
\hline 22 & P. neglectus & OR & Wheat & - & - & - & - \\
\hline 23 & P. scribneri & FL & Tomato & - & - & - & - \\
\hline 24 & P. scribneri & ND & Potato & - & - & - & - \\
\hline 25 & P. thornei & OR & Wheat & - & - & - & - \\
\hline 26 & P. zeae & / & / & - & - & - & - \\
\hline 27 & Hoplolaimus stephanus & ND & Soybean & - & - & - & - \\
\hline 28 & Tylenchorhynchus sp. & ND & Soybean & - & - & - & - \\
\hline 29 & Mesocriconema curvatum & ND & Potato & - & - & - & - \\
\hline 30 & Paratylenchus nanus & ND & Field Pea & - & - & - & - \\
\hline 31 & Pratylenchus sp. & ND & Soybean & - & - & - & - \\
\hline 32 & Helicotylenchus microlobus & ND & Soybean & - & - & - & - \\
\hline 33 & Xiphinema sp. & ND & Potato & - & - & - & - \\
\hline 34 & Non-plant-parasitic nematode 1 & ND & Potato & - & - & - & - \\
\hline 35 & Non-plant-parasitic nematode 2 & ND & Potato & - & - & - & - \\
\hline 36 & Non-plant-parasitic nematode 3 & ND & Potato & - & - & - & - \\
\hline
\end{tabular}

a DNA Code 1-13 were used in the study of Huang et al. (2018), Code 14-30 were used in the study of Huang et al. (2017b), and Code 31-36 were used in the study of Huang et al. (2017a).

${ }^{\mathrm{b}} \mathrm{Pa}, \mathrm{Pp}, \mathrm{Pm}$, and To refer to specific PCR fragment for Paratrichodorus allius, P. porosus, P. minor, and Trichodorus obtusus generated by multiplex PCR; $+/$ - stands for presence/absence of amplification.

$\mathrm{c} /$ indicates that the information was not available. 
universal primers D3A/D3B were used in PCR, confirming the presence of DNA in the unknown samples (data not shown).

Multiplex PCR for discrimination of Paratrichodorus allius, $P$. minor, $P$. porosus, and Trichodorus obtusus from artificially mixed DNA templates. The capability of multiplex PCR for simultaneous differentiation of $P$. allius, P. minor, $P$. porosus, and $T$. obtusus was investigated by using a set of artificially prepared DNA mixtures. The multiplex PCR with all five primers from the singleplex PCR protocols could generate specific fragments associated with their target DNA (Fig. 1). However, the amplification competition was observed when there were multiple targets in the PCR reaction, revealed by the unbalanced PCR products in intensity shown in the agarose gel (Fig. 1A). By increasing the annealing temperature, decreasing the concentration of reverse primers associated with abundant PCR products, and increasing the concentration of reverse primers associated with low amounts of PCR products, the optimized PCR protocol finally produced PCR fragments that could be easily distinguished from each other in the agarose gel with similar band intensities (Fig. 1B). The template from single nematode species only generated a single and relevant PCR product (Fig. 1, lanes 1-4). When the template contained more than one target, expected PCR products were amplified matching corresponding target nematodes. In detail, the banding patterns represented that the mixtures of any two targets, $P$. allius and T. obtusus, $P$. minor and T. obtusus, $P$. pororus and T. obtusus, $P$. allius and $P$. minor, $P$. allius and $P$. porosus, and $P$. minor and $P$. porosus, produced two fragments at the sizes of $421 / 425$ bp and 353 bp, 190 bp and 353 bp, 513 bp and353 bp, 421/425 bp and $190 \mathrm{bp}, 421 / 425 \mathrm{bp}$ and $513 \mathrm{bp}$, and 190 bp and 513 bp, respectively (Fig. 1, lanes 5-10). The mixtures of any three targets, $P$. allius and $P$. minor and $T$. obtusus, $P$. allius and $P$. porosus and $T$. obtusus, $P$. minor and $P$. porosus and $T$. obtusus, and $P$. allius and $P$. minor and $P$. porosus, produced three fragments at the sizes of 421/425 bp and $190 \mathrm{bp}$ and $353 \mathrm{bp}, 421 / 425 \mathrm{bp}$ and $513 \mathrm{bp}$ and $353 \mathrm{bp}, 190 \mathrm{bp}$ and $513 \mathrm{bp}$ and $353 \mathrm{bp}$, and 421/ $425 \mathrm{bp}$ and $190 \mathrm{bp}$ and $513 \mathrm{bp}$, respectively (Fig. 1, lanes 11-14). Finally, the mixture of all four targets, $P$. allius and $P$. minor and $P$. porosus and $T$. obtusus, produced four fragments at the sizes of 421/425 bp, 190 bp, 513 bp and 353 bp, respectively (Fig. 1, lane
15). Neither cross-reaction products nor amplifications with a nontemplate control that used sterilized $\mathrm{ddH}_{2} \mathrm{O}$ instead of DNA were observed in the multiplex PCR reactions.

Multiplex PCR detection of Paratrichodorus allius, $P$. minor, $P$. porosus, and Trichodorus obtusus from naturally infested soils. The ability of multiplex PCR for detecting and identifying stubbyroot nematodes was evaluated using 25 stubby-root nematode populations isolated from infested fields distributed in eight states including North Dakota, Minnesota, Florida, North Carolina, Georgia, Idaho, Oregon, and Nebraska (Table 1). All DNA extracts of single stubby-root nematodes were amplified, indicating the existence of target species. Based on the banding pattern and fragment size of multiplex PCR products, uniform amplification results were presented using three different DNA extracts of single stubby-root nematodes from one soil sample. All DNA extracts generated a single, specific fragment, and species identity was assigned according to the length of PCR products shown in the agarose gel (Table 1, Fig. 2). Among them, 18 samples producing the fragment size of $421 / 425$ bp were identified as containing $P$. allius, five samples producing the fragment size of $190 \mathrm{bp}$ contained $P$. minor, and two samples producing the fragment size of $353 \mathrm{bp}$ contained $T$. obtusus. No fragment size of $513 \mathrm{bp}$ was produced, indicating no $P$. porosus was detected. The species identities were further supported by either sequence information of ITS1 rDNA obtained from PCR amplification with BL18/5818 primers or P. allius-specific PCR.

\section{Discussion}

Molecular diagnostic tools have been broadly developed for nematode species identification which can diagnose and distinguish species regardless of nematode life stage present, eliminating the need for laborious morphometric measurements. This study describes the development, validation, and application of a one-step multiplex PCR method for detection and identification of four trichodorid nematode species, $P$. allius, $P$. minor, $P$. porosus, and $T$. obtusus, which are commonly distributed in the United States. Previous studies reported that PCR-RFLP based on 18S rRNA gene could be used to differentiate $P$. allius, $P$. porous, $P$. minor, and 18 other stubbyroot nematode species (Kumari and Subbotin 2012). However,
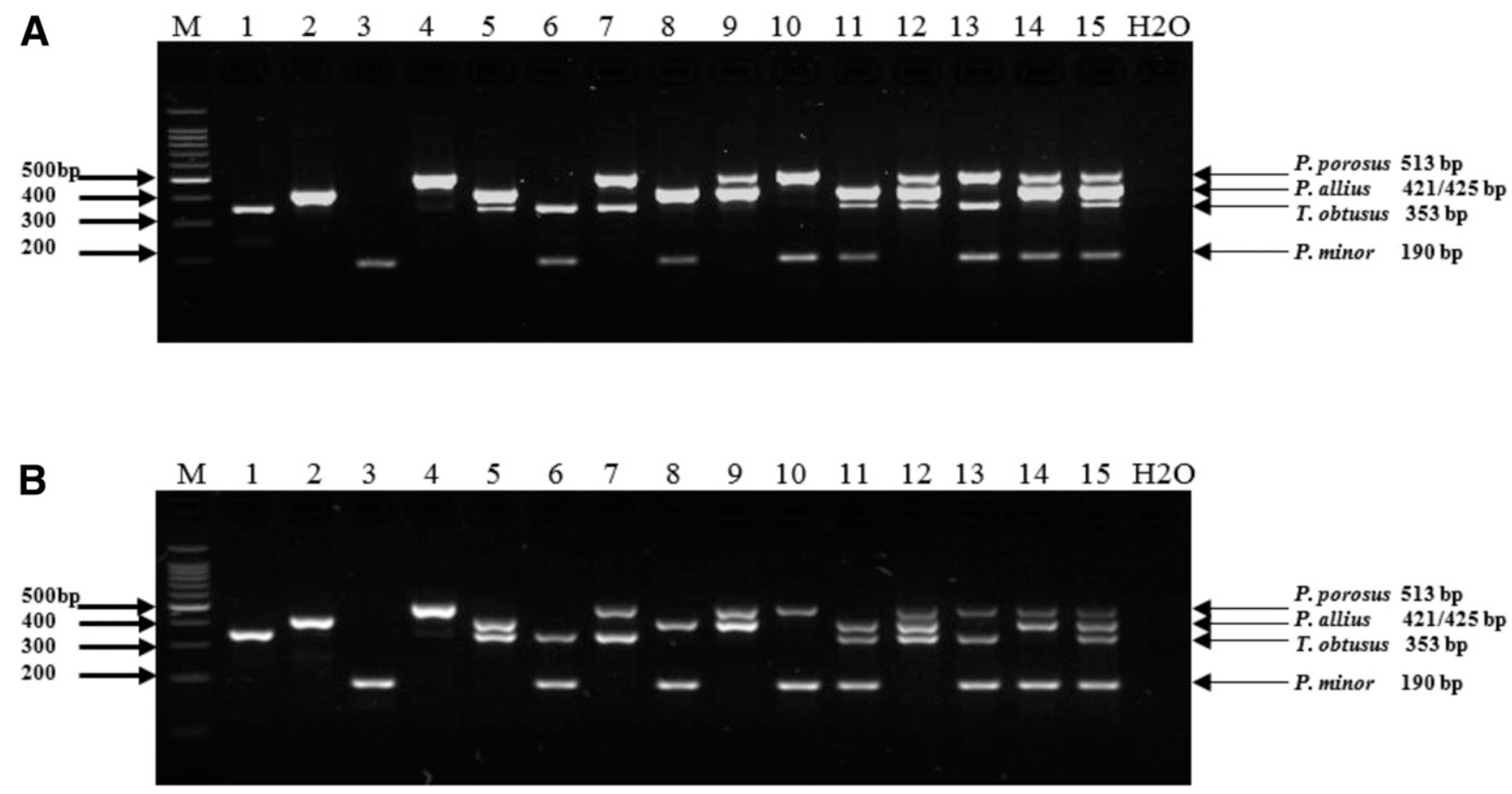

Fig. 1. Electrophoresis of multiplex PCR products with DNA from single or multiple target nematodes. (A) Multiplex PCR products using the singleplex PCR protocol. (B) Multiplex PCR products using the optimized PCR protocol. DNA templates that correspond to lanes 1-15 in the agarose gel were prepared as follows: lanes 1-4, DNA from a nematode individual of each of Trichodorus obtusus, Paratrichodorus allius, P. minor, and P. porosus; lanes 5-10, DNA mixtures from any two target nematodes; lanes 11-14, DNA mixtures from any three target nematodes; lane 15, DNA mixture from four target nematodes. $\mathrm{H}_{2} \mathrm{O}$ refers to the no template control using sterilized double distilled water in the PCR reaction instead of DNA template. M refers to 100 bp DNA ladder. 
compared with one-step multiplex PCR, the technique of PCR-RFLP requires posttreatment of PCR products with restriction enzyme digestion, a process that is time-consuming. Although end-point single PCR amplification with one pair of species-specific primers has been applied for identification of stubby-root nematode species to overcome the disadvantage of PCR-RFLP, it was only able to detect one target nematode species at one time (Boutsika et al. 2004; Holeva et al. 2006; Huang et al. 2017b). The multiplex PCR utilizing more than one pair of primers is becoming increasingly popular because of its ability to simultaneously detect multiple targets in a single PCR reaction. Multiplex PCR-based species identification methods were well-developed for many organisms, including nematodes (Filipiak et al. 2017; Hu et al. 2011; Riga et al. 2007; Wang et al. 2003).

To establish the multiplex PCR, with obvious segregation of PCR products amplified from each of the nematode species targets and with a minimal number of primers to reduce the possibility of primer competition and cross-amplification in the PCR reaction, the $18 \mathrm{~S}$ ITS1 rDNA region was selected as the target region for amplification by PCR in this study. The molecular characterization of $28 \mathrm{~S}$ rDNA, 18S rDNA, 5.8S rDNA, and ITS rDNA in $P$. allius, $P$. porous, $P$. minor, and T. obtusus revealed that $28 \mathrm{~S}, 18 \mathrm{~S}$, and $5.8 \mathrm{~S}$ regions were conserved among species while the ITS1 region was more variable (Huang et al. 2018). Therefore, more specifically, the $18 \mathrm{~S}$ region was targeted by the universal forward primer while the ITS1 region was targeted by the species-specific reverse primers.

The specificity of all primer pairs and their optimal PCR conditions are keys for a successful multiplex PCR assay (Henegariu et al. 1997). In silico analysis predicted that stable primer-template can only be formed with target species of all isolates from various geographic regions, but not with other nontarget stubby-root nematode species having ITS rDNA sequences available in GenBank. Meanwhile, the evaluation was confirmed by experimental PCR with no amplification from DNA of other common plant-parasitic nematodes and free-living nematodes. The multiplex PCR with five primers forming four pairs and targeting the four different species produced DNA fragments at desirable sizes when one, two, three, or all four species were present. The results indicated that there was no presence of primers and/or DNA template interferences in our multiplex PCR reactions. Moreover, the efficacy of primers for each target appeared to be similar, revealed by clear PCR products without much difference in band intensity shown in the agarose gel. These fragments can be easily distinguished from each other, allowing easy species identification based on fragment sizes. Previously, two trichodorid nematode species, $P$. allius and $P$. teres, could be distinguished using a single PCR reaction (Riga et al. 2007). As a comparison, the multiplex PCR developed in this study could detect more species of stubby-root nematodes through one PCR reaction, including three species of $P$. minor, $P$. porosus, and $T$. obtusus. Except for the PCR-RFLP assay (Kumari and Subbotin 2012), other molecular diagnostic tools have not been reported for these three species.

Our developed multiplex PCR assay was applied for species identification of stubby-root nematodes isolated from natural fields in diverse geographic regions. By using three individual nematodes independently, three trichodorid species, $P$. allius, $P$. minor, and $T$. obtusus, were identified in eight states, and no $P$. porosus was detected from the samples tested. In spite of the nucleotide variation in the ITS1 region among $P$. allius isolates from different regions (Huang et al. 2018), the multiplex PCR developed was able to identify all reported isolates from states of ND, MN, OR, ID, WA, and $\mathrm{NC}$, according to in silico analysis. Consistently, the experimental multiplex PCR using field samples was capable of identifying all the isolates of $P$. allius from ND, MN, ID, and OR and additionally all the isolates of $P$. allius from NE, indicating that the multiplex PCR identification approach can be broadly used for samples from different regions. Either the sequences of ITS rDNA or available speciesspecific PCR confirmed the species identity, which demonstrated the reliability of this multiplex PCR-based approach for diagnostic purpose. DNA samples used for trichodorid species detection in other studies were from adults (Boutsika et al. 2004; Riga et al. 2007). However, the multiplex PCR in this study used DNA extracts from single nematodes in different life stages (small juveniles, large juveniles, or adults), which is applicable to all common nematode samples, even for samples without adults or with low population densities lacking of adults. On the other hand, even though a mixed population of trichodorid nematodes in a field has not been found,
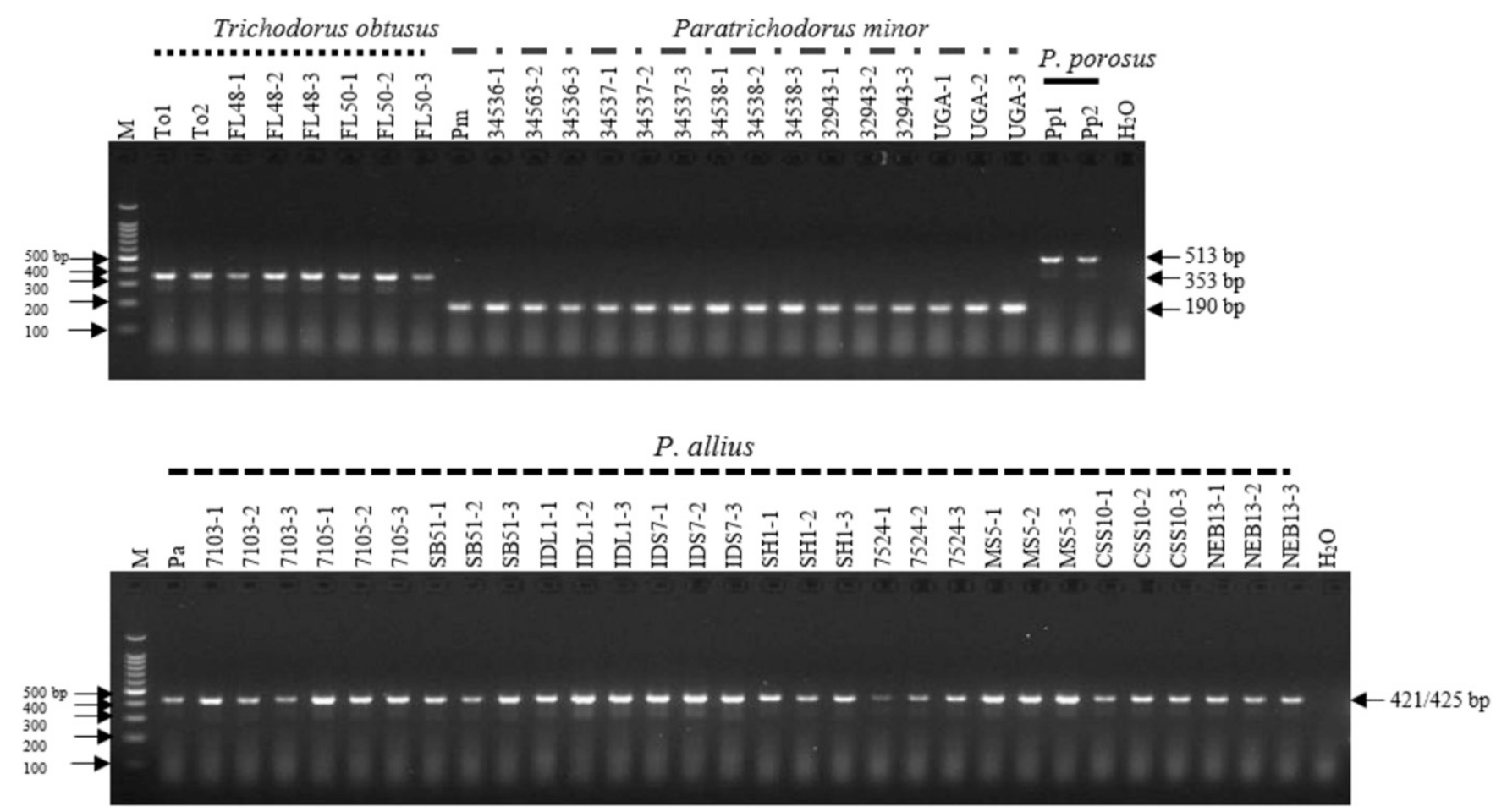

Fig. 2. Multiplex PCR assay for differentiation of stubby-root nematodes by generating species-specific PCR products. The label \#\# stands for Population ID-Replicates. To1, To2; $\mathrm{Pm} ; \mathrm{Pp} 1, \mathrm{Pp} 2$; and $\mathrm{Pa}$ are positive controls of Trichodorus obtusus, Paratrichodorus minor, $P$. porosus, and $P$. allius, respectively; $\mathrm{H}_{2} \mathrm{O}$ serves as no template control using sterilized $\mathrm{ddH}_{2} \mathrm{O}$ instead of DNA template in the PCR. M refers to 100 bp ladder. 
compared with end-point single PCR for each species, the one-step multiplex PCR approach has advantages of saving time and costs, due to running only one PCR reaction instead of attempting species-specific PCR for each of the four species. Overall, the results suggest that the described approach in this study allows simultaneous, rapid, and precise identification and discrimination of four species of $P$. allius, $P$. porosus, $P$. minor, and T. obtusus. This technique will benefit the diagnostic services and growers through associated low cost, high throughput, and relatively simple operational equipment. This study would provide useful information for further research developing multiplex PCR-based quantification of stubbyroot nematode species to meet a high demand of diagnostic services.

\section{Acknowledgments}

The authors thank Charles Brown at USDA-ARS (Prosser, WA), Paula Agudelo at Clemson University, Andrea Skantar at the USDA-ARS Nematology Laboratory, and Richard Smiley at Oregon State University for providing soil samples or DNA of control species. We are also grateful to Addison Plaisance, Arjun Upadhaya, and Intiaz Chowdhury for collecting nematodes and growers who allowed us to collect soil samples from their fields.

\section{Literature Cited}

Al-Banna, L., Williamson, V., and Gardner, S. L. 1997. Phylogenetic analysis of nematodes of the genus Pratylenchus using nuclear 26 S rDNA. Mol. Phylogenet. Evol. 7:94-102.

Boutsika, K., Phillips, M. S., MacFarlane, S. A., Brown, D. J. F., Holeva, R. C., and Blok, V. C. 2004. Molecular diagnostics of some trichodorid nematodes and associated Tobacco rattle virus. Plant Pathol. 53:110-116.

CABI/EPPO. 2002. Paratrichodorus minor [Distribution map]. Distribution Maps of Plant Diseases, October (Edition 1). Map 870. CABI, Wallingford, UK.

CABI/EPPO. 2009. Paratrichodorus porosus. [Distribution map]. Distribution Maps of Plant Diseases, October (Edition 1). Map 1066. CABI, Wallingford, UK.

Chévres-Román, R., Gross, H. D., and Sasser, J. N. 1971. The influence of selected nematode species and number of consecutive plantings of corn and sorghum on forage production, chemical composition of plant and soil, and water use efficiency. Nematropica 1:40-41.

Cho, H. J., Hong, S. W., Kim, H., and Kwak, Y. 2016. Development of a multiplex PCR method to detect fungal pathogens for quarantine on exported cacti. Plant Pathol. J. 32:53-57.

Crow, W. T. 2004. Paratrichodorus minor. EENY-339. University of Florida, IFAS.

Crow, W. T. 2005. Diagnosis of Trichodorus obtusus and Paratrichodorus minor on turfgrasses in the Southeastern United States. Plant Health Prog. 6:20.

Crow, W. T., and Welch, J. K. 2004. Root reductions of St. Augustinegrass (Stenotaphrum secundatum) and hybrid bermudagrass (Cynodon dactylon $\times$ C. transvaalensis) induced by Trichodorus obtusus and Paratrichodorus minor. Nematropica 34:31-37.

Cui, Z., Ojaghian, M. R., Tao, Z., Kahar, K. U., Zeng, J., Zhao, W., Duan, Y., Vera Cruz, C. M., Li, B., Zhu, B., and Xie, G. 2016. Multiplex PCR assay for simultaneous detection of six major bacterial pathogens of rice. J. Appl. Microbiol. 120:1357-1367.

Decraemer, W. 1995. The Family Trichodoridae: Stubby Root and Virus Vector Nematodes. Kluwer Academic Publishers, Dordrecht, the Netherlands.

Decraemer, W., and Baujard, P. 1998. A polytomous key for the identification of species of the family Trichodoridae Thorne, 1935 (Nematoda: Triplonchida). Fundam. Appl. Nematol. 21:37-62.

Decraemer, W., and Robbins, R. T. 2007. The who, what and where of Longidoridae and Trichodoridae. J. Nematol. 39:295-297.

Duarte, I. M., Almeida, M. T. M., Duarte, M. M., Brown, D. J. F., and Neilson, R. 2011. Molecular diagnosis of trichodorid species from Portugal. Plant Pathol. 60:586-594.

Filipiak, A., Wieczorek, P., and Tomalak, M. 2017. Multiplex polymerase chain reaction for simultaneous detection and identification of Bursaphelenchus xylophilus, B. mucronatus and B. fraudulentus - three closely related species within the xylophilus group. Nematology 19:1107-1116.

Hajihassani, A., Hamidi, N., Dutta, B., and Tyson, C. 2018. First report of stubby-root nematode, Paratrichodorus minor, on onion in Georgia, U.S.A. J. Nematol. 50:453-455.

Harrison, B. D., and Robinson, D. J. 1986. Tobraviruses. Pages 339-369 in: The Plant Viruses. M. H. V. Van Regenmortel and H. Fraenkel-Conrat, eds. Plenum Press, New York.

Henegariu, O., Heerema, N. A., Dlouhy, S. R., Vance, G. H., and Vogt, P. H. 1997. Multiplex PCR: Critical parameters and step-by-step protocol. Biotechniques 23:504-511.

Holeva, R., Phillips, M. S., Neilson, R., Brown, D. J. F., Young, V., Boutsika, K., and Blok, V. C. 2006. Real-time PCR detection and quantification of vector trichodorid nematodes and Tobacco rattle virus. Mol. Cell. Probes 20:203-211.

Hu, M. X., Zhuo, K., and Liao, J. L. 2011. Multiplex PCR for the simultaneous identification and detection of Meloidogyne incognita, M. enterolobii, and
M. javanica using DNA extracted directly from individual galls. Phytopathology 101:1270-1277

Huang, D., Yan, G. P., Gudmestad, N., and Skantar, A. M. 2017a. Quantification of Paratrichodorus allius in DNA extracted from soil using TaqMan Probe and SYBR Green real-time PCR assays. Nematology 19:987-1001.

Huang, D., Yan, G. P., Gudmestad, N., Whitworth, J. L., Frost, K., Brown, C., Ye, W., Agudelo, P., and Crow, W. T. 2018. Molecular characterization and identification of stubby root nematode species from multiple states in the United States. Plant Dis. 102:2101-2111.

Huang, D., Yan, G. P., and Skantar, A. M. 2017b. Development of real-time and conventional PCR assays for identifying stubby root nematode Paratrichodorus allius. Plant Dis. 101:964-972.

Ingham, R. E., Hamm, P. B., Baune, M., and Merrifield, K. J. 2007. Control of Paratrichodorus allius and corky ringspot disease in potato with shankinjected metam sodium. J. Nematol. 39:258-262.

Ingham, R. E., Hamm, P. B., Williams, R. E., and Swanson, W. H. 2000. Control of Paratrichodorus allius and corky ringspot disease of potato in the Columbia Basin of Oregon. J. Nematol. 32 (4S):566-575.

Jenkins, W. R. 1964. A rapid centrifugal-flotation technique for separating nematodes from soil. Plant Dis. Rep. 48:692.

Kumari, S., and Subbotin, S. A. 2012. Molecular characterization and diagnostic of stubby root and virus vector nematodes of the family Trichodoridae (Nematode: Triplonchida) using ribosomal RNA genes. Plant Pathol. 61: 1021-1031.

Lopez-Nicora, H. D., Mekete, T., Sekora, N., and Niblack, T. L. 2014. First report of the stubby-root nematode (Paratrichodorus allius) from a corn field in Ohio. Plant Dis. 98:1164.

Mojtahedi, H., and Santo, G. S. 1999. Ecology of Paratrichodorus allius and its relationship to the corky ringspot disease of potato in the Pacific Northwest. Am. J. Potato Res. 76:273-280.

Mojtahedi, H., Santo, G. S., Handoo, Z., Crosslin, J. M., Brown, C. R., and Thomas, P. E. 2000. Distribution of Paratrichodorus allius and tobacco rattle virus in Pacific Northwest potato fields. J. Nematol. 32:447.

Nishizawa, T. 1973. Pathogenicity of Trichodorus porosus to Chinese yam. Jpn. J. Nematol. 3:33-37.

Okubara, P. A., Schroeder, K. L., and Paulitz, T. C. 2008. Identification and quantification of Rhizoctonia solani and $R$. oryzae using real-time polymerase chain reaction. Phytopathology 98:837-847.

Rhoades, H. L. 1965. Parasitism and pathogenicity of Trichodorus proximus to St. Augustine grass. Plant Dis. Rep. 49:259-262.

Riga, E., Karanastasi, E., Oliveira, C. M. G., and Neilson, R. 2007. Molecular identification of two stubby root nematode species. Am. J. Potato Res. 84: 161-167.

Riga, E., and Nelison, R. 2005. First report of the stubby-root nematode Paratrichodorus teres, from potato in the Columbia basin of Washington State. Plant Dis. 89:1361.

Schroeder, K. L., Okubara, P. A., Tambong, J. T., Lévesque, C. A., and Paulitz, T. C. 2006. Identification and quantification of pathogenic Pythium spp. from soils in eastern Washington using real-time polymerase chain reaction. Phytopathology 96:637-647.

Shaver, B. R., Marchant, S., Martin, S. B., and Agudelo, P. 2016. 18S rRNA and COI haplotype diversity of Trichodorus obtusus from turfgrass in South Carolina. Nematology 18:53-65.

Shaver, J. B., Agudelo, P., and Martin, S. B. 2013. First report of stubby root caused by Trichodorus obtusus on zoysiagrass and bermudagrass in South Carolina. Plant Dis. 97:852.

Sheedy, J. G., Clewett, T. G., Hodda, M., and Thompson, J. P. 2010. First record of stubby-root nematode (Paratrichodorus porosus) associated with barley in Australia. Australas. Plant Dis. Notes 5:66-69.

Thompson, J. D., Gibson, T. J., Plewniak, F., Jeanmougin, F., and Higgins, D. G. 1997. The CLUSTAL_X windows interface: Flexible strategies for multiple sequence alignment aided by quality analysis tools. Nucleic Acids Res. 25: 4876-4882.

Wang, X., Bosselut, N., Castagnone, C., Voisin, R., Abad, P., and Esmenjaud, D. 2003. Multiplex polymerase chain reaction identification of single individuals of the longidorid nematodes Xiphinema index, $X$. diversicaudatum, $X$. vuittenezi, and $X$. italiae using specific primer from ribosomal genes. Phytopathology 93:160-166.

Yan, G. P., Khan, M. F., Huang, D., Lai, X., and Handoo, Z. A. 2016a. First report of the stubby root nematode Paratrichorodorus allius on sugar beet in Minnesota. Plant Dis. 100:1022.

Yan, G. P., Plaisance, A., Huang, D., Upadhaya, A., Gudmestad, N. C., and Handoo, Z. A. 2016b. First report of the stubby root nematode Paratrichodorus allius on potato in North Dakota. Plant Dis. 100:1247.

Yan, G. P., Smiley, R. W., and Okubara, P. A. 2008. Detection and discrimination of Pratylenchus neglectus and P. thornei in DNA extracts from soil. Plant Dis. 92:1480-1487.

Ye, W., Zeng, Y., and Kerns, J. 2015. First report of Trichodorus obtusus on turfgrass in North Carolina, U.S.A. Plant Dis. 99:291.

Zeng, Y., Ye, W., Bruce Martin, S., Martin, M., and Tredway, L. 2012. Diversity and occurrence of plant-parasitic nematodes associated with golf course Turfgrasses in North and South Carolina, USA. J. Nematol. 44:337-347. 